\title{
The Religious Predisposition
}

\author{
Johannes Bronkhorst \\ Emeritus Professor, Faculty of Arts, University of Lausanne, Lausanne, \\ Switzerland \\ johannes.bronkhorst@unil.ch
}

\begin{abstract}
This article first predicts, on the basis of an analysis of deep absorption, a number of features of mystical and related states of consciousness. It then observes that these very same features appear in beliefs held by people who have never experienced deep absorption. Moreover, many people engage in activities that, though not normally leading to deep absorption, bring about lesser states of absorption. The article will propose an answer to the question how it is that many people are influenced in their beliefs and practices by experiences (deep absorption) they have not had.
\end{abstract}

\section{Keywords}

mental absorption - mystical experience - mystical thought - lantern consciousness memory

This article first predicts, on the basis of an analysis of deep absorption, a number of features of mystical and related states of consciousness. It then observes that these very same features appear in beliefs held by people who have never experienced deep absorption. Moreover, many people engage in activities that, though not normally leading to deep absorption, bring about lesser states of absorption. The article will propose an answer to the question how it is that many people are influenced in their beliefs and practices by experiences (deep absorption) they have not had. ${ }^{1}$

1 The crucial concept in this article is mental absorption. Since no way to measure depth of absorption in neurophysiological terms is available as yet, neuropsychology turns out to be 
What is absorption? Absorption is another name for the faculty of concentration or focused attention. ${ }^{2}$ This faculty enables humans (and many other animals) to fix their minds on something specific and exclude or reduce associative links (including non-pertinent sense impressions) (e.g., Desimone \& Duncan 1995). The exclusion or reduction of associative links is the aspect of absorption to be discussed in the following pages. ${ }^{3}$ We know this aspect of absorption from everyday experience and from numerous experiments-among which that of the "invisible gorilla" is well known (Chabris \& Simons 2010). ${ }^{4}$ Indeed, "attention is regarded as a limited power supply. The basic idea is that attention represents a general-purpose limited capacity that can be flexibly allocated in many different ways in response to task demands." (Eysenck 1982: 28). "Any intensification of focal attention necessitates the elimination of distracting or irrelevant stimuli.... We not only pay attention to our given task but also ward off distractions." (Spiegel \& Spiegel 2004: 19). Attention, moreover, appears to be domain-general, i.e., it is to a large extent shared between mental processes regardless of the nature of the information involved (Vergauwe, Barrouillet \& Camos 2010).

Concentration excludes or reduces mental associations that we could be aware of if we were not concentrating on something else. However, there are also mental associations that we could not be aware of and which nevertheless play a role in ordinary awareness. Our awareness is "colored" (without us being aware of the coloring) by memories, expectations and concepts to which we do not have immediate conscious access; it is colored by other mental contents, some of which are not conscious: "studies have shown that unconscious processing can influence awareness." (Berlin 2011: 6). The mental associations we are not aware of are responsible for the fact that ordinary awareness is interpreted awareness. Numerous authors have observed this (among others Lotto 2017; Searle 2010; Hoffman 1998; 2012; Dennett 2017:169 f.,

of little use to support or refute the theory presented (see $\S 7$ and note 14). The use of theories that base themselves on the presumed evolutionary benefits of certain behaviors and beliefs will be discussed in $\S 7$.

2 When discussing the effects of deep absorption (as we will do below), I prefer absorption to attention. Research has shown that there can be unconscious attention (see, e.g., Chou \& Yeh 2012); this does not appear to be true of deep absorption.

3 The focusing aspect of absorption will not be dealt with; it may need a study of its own. It is possible, but not certain, that this focusing aspect is responsible for the way attention is known to affect appearances (Watzl 2019).

4 For a neuronal model of "inattentional blindness", see Dehaene \& Changeux 2005. 
with a reference to Mordvintsev et al. 2015): "What I perceive are not the crude and ambiguous cues that impinge from the outside world onto my eyes and my ears and my fingers. I perceive something much richer-a picture that combines all these crude signals with a wealth of past experience." (Frith 2007: 132). "We perceive through our sensory organs, to be sure, but no less through our concepts; in other words, we perceive not just physiologically but also intellectually." (Hofstadter \& Sander 2013: 171). ${ }^{5}$ Among the elements that "feed into" awareness, proprioception and interoception deserve special mention. They are responsible for the constant implicit presence of a person's body in their awareness, and they contribute to the resulting sense of self. Indeed, "interoceptive re-representations ... substantialize (that is, provide de basis for) all subjective feelings from the body and perhaps emotional awareness, ...". (Craig 2009: 59; see further Craig 2015). Emotions play a role in determining how we experience the world; interestingly, these too are made rather than passively experienced (Barrett 2017). Mood can have a measurable effect on visual perception, and this confirms, once again, that ordinary awareness is interpreted awareness, and that this interpretation can be variable (Antinori, Carter \& Smillie 2017). Culture, too, can have an effect on the way we process the world (Nisbett 2003). Numbers, for example, influence awareness in the cultures that have them (Everett 2017).

It follows that sensory and other impressions that we become aware of are ordered and made sense of in the light of earlier experiences and reflections even before we become aware of them. ${ }^{6}$ Our experiences, therefore, are embedded in webs of associations that connect them with other mental contents. Searle (2010: 31-32; 2015: $36 \mathrm{ff}$.) speaks in this connection of the Network or the Background, and says in his latest book (2015: 73): "What I am arguing is that the interpretation of a visual experience ... will be a function of the conceptual apparatus that the interpreter brings to the experience." Indeed, "[i]n conscious perception, images are continually called up from memory, then modified by the new, incoming sensory information into an updated image of the world as it is being experienced." (Feinberg \& Mallatt 2016: 2583). The driving force behind these associations appears to be analogy, which some look upon as the core of cognition (Hofstadter \& Sander 2013; Leech, Mareschal \& Cooper 2008).

These considerations confirm that awareness is by its nature variable. It varies, of course, depending on what it is 'about': the awareness of a table is

5 The "inner" contribution to perception is so important that the mere thought of a bright light changes the size of one's pupils; Zokaei et al. 2019.

6 This and the following paragraph occur in similar words in Bronkhorst 2017: 6. 
different from the awareness of a chair. More importantly, it also varies in accordance with the conscious or unconscious associations that contribute to it: Marcel Proust's awareness of the cakes called petites madeleines was colored by memories from his childhood, and no doubt different from the way others (or he himself at other occasions) would perceive these cakes. And our normal perception of a banknote is colored by mental associations that assign value to it: those who do not have these associations will see only a piece of paper. In fact, one has to draw on past experience even to know that it is paper. This coloring is perhaps most prominent in our awareness of other human beings: we experience our mother, or our monarch (if we have one), not just as the persons they are, but also in terms of the social roles they play. ${ }^{7}$

This takes us back to absorption. Is it possible for concentration to expand into the realm of mental associations that one is not ordinarily aware of? Is it in the nature of concentration to only reduce or suppress mental associations that are accessible to consciousness, or can it go beyond these? If the former, absorption will not be able to reduce or suppress mental associations that are not accessible to consciousness. In the latter case, must we assume that absorption can do so, but requires, or is facilitated by, an expansion of the realm of mental associations accessible to consciousness?

These are important questions, which will occupy us later in this study. Until then, we will simply assume that deep absorption can indeed reduce or suppress mental associations with contents and inputs of which we are not normally aware, which lie below the threshold of consciousness, but which yet do play a role in ordinary awareness. Since these associations contribute to the way we cognize the world and ourselves, mental absorption, if deep enough, must then be expected to have cognitive effects.

What cognitive effects can we expect a strong reduction of such mental associations to have? Ordinary awareness, as we have seen, is interpreted awareness, which means that experiences are embedded in webs of associations. A weakening of these webs should give rise to differently interpreted experience. This will then affect both our experience of the outside world and of ourselves. Let us consider these separately.

The experience of our surroundings is colored by various associations. When we see a cup, we recognize it as a cup, we implicitly know what a cup is for, etc. If and when the associative connections with past experiences fall away, we may see the same cup, but we will not recognize (i.e., re-cognize) it as

7 We are not at present concerned with the question what mental associations color our awareness (some of which may be determined by our cultural background), but rather with the observation that mental associations do so. 
a cup. We will not know what it is for and, to put it briefly, we may experience it as something totally novel. Since language plays a role in creating the associations that contribute to the interpretation of experience, ${ }^{8}$ experience may present itself as ineffable, beyond the realm of words. Experience will now be differently_perhaps one can say: less -interpreted, and therefore different. This new experience, being freed of the "burden" of associated mental contents, may be felt as being more real, or even as giving access to a reality different from the reality experienced in ordinary states of mind. ${ }^{9}$

There are further consequences. Since ordinary awareness is colored by memories, expectations and other concepts, awareness without (or with less) coloring of that kind may be experienced as involving a different sense of time, or even as timeless, as an eternal present. Ordinary awareness situates itself between past and future and is therefore experienced as having limited duration. Without such a temporal context, time itself will be experienced differently.

Deep absorption will also affect the sense of self. The awareness of ourselves accompanies us in all "normal" states of awareness, but is a construction built on the basis of numerous experiences, memories and other concepts. ${ }^{10}$ It depends on a large number of associative connections. Several thinkers emphasize the narrative nature of this sense of self (e.g. Dennett 1991: 417-18). Bruce Hood (2012: 6o) emphasizes the importance of memories:

Our identity is the sum of our memories, but it turns out that memories are fluid, modified by context and sometimes simply confabulated. This means we cannot trust them and our sense of self is compromised. Note how this leaves us with a glaring paradox - without a sense of self, memories have no meaning, and yet the self is a product of our memories.

Hood argues at length that the self is an illusion, and observes (p. 214):

The self illusion depends on stored information that has been acquired during a lifetime. These are our memories that are constructed as we interpret the world. That interpretation is guided by mechanisms that seek out certain information in the world but also by those around us who help us to make sense of it all.

8 This issue is explored in Bronkhorst 2010 / 2012a.

$9 \quad$ On the "reality" of this different "reality", see Appendix 1.

10 Watzl (2018) argues that all forms of consciousness reveal a phenomenal self in active attention. 
Since it weakens associative connections, deep absorption is likely to break through this illusion, with profound effects on the way we experience ourselves and the world.

Antonio Damasio distinguishes between core consciousness and extended consciousness. The former is of a nonverbal nature. However, autobiographical consciousness relies extensively on language (Damasio 2010: 172). Indeed,

language contributes massively to the way we experience the world, in particular to our sense of the self as our narrative center in the past and present. But our basic experience of the world does not depend on it.

КОСН 2O19: 1036

With the weakening or disappearance of autobiographical consciousness, consciousness as such does not disappear, but it will be without a sense of self, or with a reduced or modified sense of self.11

The disassociation from the autobiographical sense of self has an important consequence, viz. that one is no longer associated with what one has done and what one is going to do. What is more, one no longer identifies with one's actions.

This analysis of the cognitive effects of a weakened web of mental associations, as simple as it may appear, draws attention to a potential realm of experience that is far removed from the ordinary experience of most people in their daily lives. This realm of experience, if and to the extent it is produced by sufficiently deep absorption, may be reported as being characterized by the following features:

(i) access to a different, "higher", reality;

(ii) a different sense of time, perhaps culminating in a sense of timelessness;

(iii) a different sense of self, potentially separating one's self from one's actions;

(iv) ineffability.

Our analysis also shows that this extraordinary realm of experience is not just something that a dysfunctional brain might produce in its unfortunate owner. On the contrary, such experience is the predictable outcome of entering into a state of mental absorption, if only this state is deep enough.

11 This is not quite how Damasio puts it when he says, e.g., that "if one is awake and there are contents in one's mind, consciousness is the result of adding a self function" (p. 166). However, his core consciousness is "the sense of the here and now, unencumbered by much past and by little or no future. It revolves around a core self and is about personhood but not necessarily identity." (p. 168; my emphasis). 
Can there be states of mental absorption of such depth in real people? States whose depth is such that there are noticeable cognitive effects do not normally affect most of us. On the other hand, many people experience states of absorption of some depth (e.g., Hardy 1979; Hay 199o; The Mystical Experience Registry [http://www.bodysoulandspirit.net/mystical_experiences/]). ${ }^{12}$ They are often referred to as "religious experiences" ("deemed religious"; Taves 2009), ${ }^{13}$ which can be of varying depths. Absorption also accompanies hypnotic trance, the state called "flow", intense prayer, orgasm and much else. Absorption in many of those is not particularly deep. ${ }^{14}$

All of this complicates the task of verifying the claim that deep absorption can be responsible for the features enumerated above. As it is, we have so far little beyond impressions to go by. But these impressions are not worthless. Accounts by religious mystics who claim to have lived through deep mystical experiences (i.e., deep absorption) frequently mention these features, even though obviously adapted to their religious and cultural contexts. Already William James (1902: 367) drew attention to the ineffability of mystical experiences. Another feature he emphasized is the noetic quality of these experiences, providing "insight into depths of truth unplumbed by the discursive intellect". This corresponds, of course, to knowledge of a "higher", or "deeper", reality that we expect, on the basis of our earlier reflections, states of deep absorption to provide. The changing sense of self, which our analysis makes us expect, is so central that Evelyn Underhill (1911) dedicated a major part of her classical study of European mysticism to it, with chapter headings such as "The Awakening of the Self", "The Purification of the Self", "The

12 Hay (1990: $79 \mathrm{ff}$ ) gives "international statistics" that suggest that religious experiences are far from uncommon.

13 Not always. See, e.g., Austin 1998: 71: "during rare moments, [...] meditators may [...] make a major shift into an extraordinarily different mode. It is a shift that carries the properties of clarity, persistence, and concentration far beyond their ordinary limits. Now, as attention transforms itself, [...] it reaches that state called absorption. [...] Absorptions convey the sense of being held, transfixed, and riveted. It is a process during which extra, concentrated energy involuntarily infuses the act of attention." See also Austin 2006: $313 \mathrm{ff}$.

14 There is no generally accepted objective (e.g., neurophysiological) scale measuring the depth of absorption. Even if there were one, it would be difficult to use it in many of the most interesting instances: Experiences that can sometimes reach great depths of absorption-especially religious experiences-tend to arrive at unforeseen moments. Cp. Ott's (2007: 262) observation, that is still true today: "standards for the definition and assessment of states of absorption have not been established thus far." Watzl (2011: 847) draws attention to some of the difficulties: "Scientific research ... suggests that the class of sub-personal attentional processes is highly diverse and not well localized in the brain." See below $(\$ 7)$ for the need for neurophysiological measurements of depth of absorption. 
Illumination of the Self". The different experience of time that we expect is frequently expressed, for example in a preoccupation with Eternity (Underhill 1911: passim).

Let me add at this point, perhaps superfluously, that the features here discussed will be interpreted, or even experienced, in ways that are colored by the cultural context of the person concerned, and by their personal life-history. The present article does not deal with these coloring factors and is exclusively concerned with the underlying features that find expression through these colorings.

Scholars have tried to determine the "common core" of mysticism, without coming to an agreement (e.g. Stace 196o: 44, 79, 110-111, 131-132; Kimmel 2008). Their search is not ours, for we are not looking for a universal core of mysticism. Our search is more modest and can be more easily confronted with the data. Our theory predicts that the features identified above have a certain likelihood to appear in reports of those who have undergone states of deep absorption. They do not need to appear in all such reports. Nor do we need to worry whether the authors of these reports were all of them bona fide mystics (i.e., people who had really experienced states of deep absorption): many may not have been (see below; §3). The regular appearance of these features in reports of those who claim or were generally believed to have undergone deep mystical experiences is at present the best we can hope for. And this hope is amply fulfilled.

Religious mystics are not the only ones to provide evidence for what the experience of deep absorption is like. Hypnotism does not usually go that deep, but in exceptional cases it does. Tart's (1983: 191-200) account of a student ("William") who reached extraordinary depths of hypnotic trance is of great interest. William "reports that after a depth of 50 [on the Extended North Carolina Scale; JB] it does not make sense to ask him about physical relaxation because he is no longer identified with his body; his body is 'just a thing, something I've left behind.' One does not rate the relaxation of things." After a depth of 60 "there is no longer a self to be peaceful or not peaceful"; "his ordinary identity continues to decrease until around 8 o or 90 he feels that his ordinary identity is completely in abeyance: 'William' no longer exists." Regarding time, "William feels time passing more and more slowly in a linear fashion as he goes down to about 40.... William feels that time suddenly ceases to be a meaningful concept for him: at 50 he is no longer in time, his experiences are somehow timeless, they do not have a duration or a place, an order in the scheme of things." These are all features that our analysis of deep mental absorption prepared us to expect. 
Let me emphasize at this point that I have not extracted the predictions here considered from reports produced by those who have experienced deep absorption; they are rather a priori predictions of what such experiences can be like if indeed deep absorption is responsible for them, at least in part. Existing reports of such experiences - to the extent that they mention these featurescan therefore be taken to support this theory. And they answer in an affirmative manner the question whether such states of deep mental absorption can exist. Yes, they can. But we will see that this does not answer all questions.

\section{3}

Mystical Experience and Mystical Thought

The features that we associate with deep absorption are not limited to situations in which someone has actually experienced a state of absorption of the necessary depth. The same or similar features appear in communications where there is no evidence for mystical experience whatsoever. This has prompted many scholars to unjustifiably postulate mystical experience in such cases. This is a frequent phenomenon, so that just one recent and particularly clear example must suffice. The Editor's Introduction to The Cambridge Handbook of Western Mysticism and Esoterism (Magee 2016) claims that all that is typically categorized as "mystical" alludes to a life transforming and inexpressible experience of what it calls gnosis (p. xvi). The doctrines of mysticism, moreover, are an attempt to put the wordless into words, to communicate what is revealed in gnosis (p. xviii). The Editor's Introduction then characterizes some common features in those doctrines, and states (p.xvii):

This doctrine is perhaps most starkly laid out in Vedanta, in the identity between Atman (one's true self or nature) and Brahman (the transcendent source of all being) - but the same teaching is to be found in Eckhart.

The authors of Vedanta and Meister Eckhart are given as illustrations of the attempt to express mystical experience into words. The Editor's Introduction makes no attempt to show that these authors ever had such an experience, apart from stating that "in one way or another it alludes to such an experience". Worse, Meister Eckhart, sometimes considered the founder of Rhineland mysticism, never claimed to have experienced anything of the kind (Hackett 2013: xxii-xxv). He may not have been the only one. The chapter on medieval Christian mysticism of the Handbook observes (Milem 2016: 116): 
some of the writers who are usually acclaimed as mystics, such as Eckhart, Eriugena, and Cusanus, do not emphasize experiences or visions. Their mysticism consists in a particular way of thinking about God that tries to articulate how God is present in ordinary things and everyday experience. All three use a dialectical or paradoxical mode of speech that balances contrary descriptions of God against each other. Although God is identical with ordinary things, God is also absolutely transcendent and unlike them. Following their path of thinking may not lead to any special, peak mystical experiences, but it can infuse all things with a new significance as expressions or images of God.

The claim that the authors of Vedanta ever had an experience of this sort has nothing to support it. ${ }^{15}$

The Handbook does not only deal with mysticism. As its title indicates, it also concerns esotericism. Esotericism, too, we read in the Editor's Introduction (Magee 2016: xxix), "is founded on gnosis, either directly (when esotericists themselves have the experience of gnosis) or indirectly (when esotericists put their faith in the testimony of those who have had the experience)." Indeed, everything treated in the Handbook as esotericism "-alchemy, astrology, magic, number symbolism, visions of other worlds, spiritualism, and so on-is founded in one way or another on the mystical teaching of hen kai pan (One and all), and everything that it entails" (p.xxix).

Claims like this put a heavy burden on the shoulders of those who have had "mystical experiences". If it is true, important cultural traditions would not be there if mystics had not reported their experiences, or if people had not listened to them. Given this importance, one would think that it is vital to show that recognized mystics actually had, or had had, such experiences.

The Handbook is of not of much use in justifying such claims. The word experience does not even figure in the index, and experiences are not very often referred to. This does not mean that none of the individuals included had mystical experiences; there are cases where no doubt seems justified. It does however mean that it is advisable not to attribute such experiences too easily to individuals for the sole reason that they proclaim "mystical teachings". If certain mystical teachings are widespread - and the Editor's Introduction (p. xxxi n. 24) suggests that they are universal and cross-culturally valid-we may have to consider alternative explanations for their popularity. Such alternative explanations are still required even if we were to accept that mystical

15 This does not exclude, of course, that there may have been individuals associated with Vedanta who had mystical experiences; an example would be Ramakrishna (see Sil 1991). 
experiences are their ultimate source (which we seriously doubt): for why should people "put their faith in the testimony of those who have had the experience", as the Editor's Introduction puts it? Why believe the claims of "real mystics" rather than the invented claims of "false mystics" or other charlatans? Unless there is a predisposition to accept certain views, the teachings of those who have had mystical experiences run the risk of not being valued and might soon be forgotten. ${ }^{16}$ But if there is such a predisposition, is there then still need for mystics to propound those views?

One of the contributors to the Handbook-Bruce Milem, author of chapter 10, on medieval Christian mysticism-presents a view that is rather different from the one espoused by its editor. His remarks are worth quoting (Milem 2016: 107-108):

"Mysticism" is a modern designation that became widespread in the late nineteenth and early twentieth centuries. The first scholars of mysticism, such as William James, Evelyn Underhill, and Rudolf Otto, focused on what they called mystical or religious experience, which they thought was the root of all religion. This emphasis on experience is characteristically modern, in harmony with doubts about tradition, authority, and institutions, and congruent with modernity's confidence in the experiential basis of science.

Milem then continues:

Because of the modern origins and character of the concept of "mysticism", we have to be careful when looking for mysticism in medieval Christianity. It is not that medieval people did not have, or were not interested in, extraordinary experiences of union with God. Rather, medieval people did not put the same weight on experience as an authority different from tradition, Scripture, and church that modern people do. They expected these authorities to agree. Moreover, medieval thinkers typically put experiences of God within the context of the Christian's gradual transformation into a perfected human being who enjoyed some sort of union or identity with God. This transformation, enacted in central

16 This is not to deny that there are other factors that tempt people to accept certain beliefs, among these "cultural attractors"; see, e.g., Boudry \& Braeckman 2012; Boudry, Blancke, \& Pigliucci 2015. Unlike many of those other factors, which are by and large culturally determined, the features of "mystical thought" specified above are universal (even though their specific expressions will be colored by the ambient culture). 
Christian rituals such as baptism and communion, is what mattered, not the experiences. Still, some writers in the Middle Ages explored or emphasized the possibility that union with God is available in this life rather than exclusively in heaven ... While some of these writers saw union as the basis for extraordinary experiences, others understood union as a permanent state of being that Christians would attain.

Seen this way, the belief in (or expectation of) union with God can hardly be the outcome of direct or indirect influence by mystics, and the presence of this "mystical" notion in medieval Christianity clamors for another explanation.

All this leaves us with a peculiar problem. If there can be mystical thought without mystical experience, we no longer need mystical experience to explain mystical thought. ${ }^{17}$ And yet, I consider it probable that there have been and are people who have mystical experiences and describe those experiences in terms that we also find in mystical thought. Who, then, influenced whom? Or is there no need to postulate influence?

It may not be easy to find a generally valid answer to this question. Assuming that Meister Eckhart did indeed not have mystical experiences, was he influenced by the writings or teachings of "real" mystics, i.e., mystics who had had them? If so, why did he consider those teachings significant? And why did his followers consider his teachings significant? We are confronted with the general question why mystical teachings appear significant to people who have not had mystical experiences themselves. Our line of enquiry takes us away from "real" mystics - those with mystical experiences — and toward the psychology of "ordinary" people, those who may draw inspiration from mystical teachings that may or may not derive from people who have had mystical experiences. ${ }^{18}$

It is time to return to our analysis of absorption. We saw that the assumed consequences of deep absorption made sense of many experiences reported by mystics and others. Many of the "ordinary" people who follow the teachings of "real" mystics presumably never had such experiences. Remember at this point that the line separating deep absorption from less deep absorption

\footnotetext{
17 It also further reduces the appeal of the claim that Indian philosophical theories arose from spiritual practice; see Franco 2018.

18 These observations may delight scholars who think that belief in "mystical thought" should be explained in terms of evolutionary psychology; see, e.g., Gorelik 2016; Gorelik \& Shackelford 2017. However, even if it can be shown that "mystical thought" brings evolutionary benefits (a question that this article does not address), this cannot be construed as a criticism of the mechanism that brings it about (such as the one proposed in this article). See further $\S \S 7$ and 8 , below.
} 
is not hard and fast. Many people can experience flow or become absorbed in contemplating art or listening to music. Is it possible that the limited degrees of absorption to which many people have access give them an intuitive awareness that the world can be experienced differently?

This "solution" only shifts the problem. What does it mean that people have an intuitive awareness of mental states that they have not experienced? I propose the following answer: They have experienced such states, in early childhood. As a result, when people are confronted with so-called mystical teachings, they recognize elements. In a sense of remembering that will be specified below, they remember that they once experienced the world without a developed sense of self, that the world was once uninterpreted, or minimally interpreted. ${ }^{19}$ This is the thesis that will be further explored in what follows. But first more need be said about altered states of consciousness.

\section{4}

\section{From Buddhism to Childhood}

Little has been said so far about meditation. Yet certain forms of meditation deal with states of deep absorption. A look at some early Buddhist texts ${ }^{20}$ will suggest how to understand the processes involved.

The early Buddhist path contains a number of stages, two of which are of particular interest in the present context. A number of levels of deep absorption are part of it, but they are neither its beginning nor its end. These levels are preceded by preparatory practices, among which the practice of mindfulness is very important. There is no better way to compare and contrast the two - mindfulness and levels of absorption - than through a literal quotation of the most relevant passage from the early texts. Here we read (Bodhi 1995: 274-275, modified):21

(1) He becomes one who acts in full awareness when going forward and returning; who acts in full awareness when looking ahead and looking away; who acts in full awareness when flexing and extending his limbs; who acts in full awareness when wearing his robes and carrying his outer

19 The thesis here proposed should not be confounded with the idea of regression as propounded by Sigmund Freud and others (I thank Oliver Kress for reminding me of this).

20 The assumption that all or many Buddhists were accomplished meditators is certainly incorrect; see Appendix 2.

21 This translates Majjhima Nikaya I p. 181-182. This same passage occurs numerous times in the ancient Buddhist canon; see Schmithausen 1981: 204 n. 15. For details on early Buddhist teaching, see Bronkhorst 2009. 
robe and bowl; who acts in full awareness when eating, drinking, consuming food, and tasting, who acts in full awareness when defecating and urinating; who acts in full awareness when walking, standing, sitting, falling asleep, waking up, talking, and keeping silent.

(2) Having thus abandoned these five hindrances, imperfections of the mind that weaken wisdom, quite secluded from sensual pleasures, secluded from unwholesome states, he enters upon and abides in the first stage-of-meditation that is born of seclusion, which is accompanied by applied and sustained thought and consists of rapture and pleasure. [...]

Again, with the stilling of applied and sustained thought, a monk enters upon and abides in the second stage-of-meditation, which has selfconfidence and singleness of mind without applied and sustained thought, which is born of absorption and consists of rapture and pleasure. [...]

Again, with the fading away as well of rapture, a monk abides in equanimity, and mindful and fully aware, still feeling pleasure with the body, he enters upon and abides in the third stage-of-meditation, on account of which the noble ones announce: 'He has a pleasant abiding who has equanimity and is mindful.' [...]

Again, with the abandoning of pleasure and pain, and with the previous disappearance of joy and grief, a monk enters upon and abides in the fourth stage-of-meditation, which has neither-pain-nor-pleasure and purity of mindfulness due to equanimity. [...]

The first part of this passage (1) describes mindfulness, the second (2) the four stages-of-meditation.

I have elsewhere interpreted this passage in the light of a theory that distinguishes, and contrasts, the implicit and the explicit systems of mental functioning (Bronkhorst forthcoming). "The explicit system is a sophisticated system that is tied to consciousness and thus capable of representing knowledge in a higher-order format. In contrast, the implicit system is inaccessible to consciousness." (Dietrich \& Haider 2017: 3-4). The implicit system is responsible for automatic behavior and activities that are not in need of conscious supervision and may even resist it. Mindfulness, as can be learnt from the first part of the above quotation, aims at expanding the realm of the explicit system and reducing the realm of the implicit system. This, in turn, facilitates greater depth of absorption. ${ }^{22}$

22 The assumption that the realms of the explicit and implicit systems are variable finds support in the finding that anxiety and cognitive load (which presumably put a greater demand on the implicit system) reduce attention control; Shi et al. 2019. 
The Buddhist text here cited distinguishes between two kind of mental practice: mindfulness and absorption. The two are not unrelated, because mindfulness is presented as preparatory to absorption but is still present in the deepest stages-of-meditation. And yet, they lead to distinguishable mental states. While mindfulness attempts to open up an awareness that is as broad as possible, absorption unites it to a maximum degree. It appears that the greater openness created by mindfulness allows greater unification, in the form of absorption, of the extra "space" that mindfulness provides. The process may even be bidirectional: deep absorption penetrates into the realm of the implicit system and thus creates space for greater mindfulness. The mutual interplay of the two facilitates the attainment of deeper states. ${ }^{23}$

For our present purposes it is useful to distinguish between the mental states resulting from mindfulness and absorption respectively. This distinction will help us understand the state of awareness of young children, to which we now turn.

How do children experience the world? Recent work by Alison Gopnik, a psychologist, may provide an answer. Gopnik compares the external consciousness of adults to a spotlight and contrasts this with attention in children, which is more like a lantern (Gopnik 2009: 124):

It's plausible that babies are actually aware of much more, much more intensely, than we are. The attentional spotlight in adults seems more like an attentional lantern for babies. Instead of experiencing a single aspect of their world and shutting down everything else they seem to be vividly experiencing everything at once....

Babies also seem less subject to certain kinds of unconsciousness than we are. Less of their experience is familiar, expert, and automatic, and so they have fewer habituated unconscious behaviors. While they inhibit distractions less well, more of the field of consciousness will be available to them.

Translated in terms of the notions of an explicit and an implicit system of mental functioning here adopted, this becomes: In relative terms, the realm of the explicit system is larger in babies than in us, the realm of the implicit system is smaller. The mental state that adults can only reach through a combination of mindfulness and absorption is freely available to infants.

23 It is not impossible that mindfulness and absorption vaguely correspond to meditation and contemplation in some of the senses in which the latter terms were used in Western European Christianity; see Baier 2019. 
Consciousness, Gopnik maintains, narrows down as a function of age: "As adults, when we pay attention, we are regressing a little part of our brain to its childhood state. We are taking a little part of us and turning that into a 2-yearold again." ${ }^{24}$ This quotation confirms what I suggested earlier, viz., that attention penetrates into the realm of the implicit system and thus creates space for greater mindfulness, i.e. baby consciousness (see below).

In order to clarify what the child's consciousness is like, Gopnik makes a comparison with different kinds of meditation (Gopnik 2009: 127):

Meditative practices involve manipulating attention in novel ways. In some of these traditions, the idea is to focus and sustain vivid attention on a single object - a mandala or a koan or a crucifix. But in other types of meditation the idea is to distribute attention as much as possible. Certain types of "open awareness" meditative practices are about not focusing on a single object.

This second type of meditation is "like the lantern consciousness of childhood as opposed to the spotlight consciousness of ordinary adult attention". Gopnik argues "that this expansive lantern consciousness is almost the opposite of the distinctive adult happiness that comes with what psychologists call 'flow'". (Gopnik 2009: 129). Our discussion so far suggests that this distinction corresponds to the distinction between mindfulness and deep absorption. Children's consciousness corresponds to the state that mindfulness practice seeks to attain: expansion of the realm of the explicit system at the expense of the realm of the implicit system. Unlike adults, young children need make no effort to get there; they are there already. This explains that babies seem less subject to certain kinds of unconsciousness than we are, that less of their experience is familiar, expert, and automatic, and that they have fewer habituated unconscious behaviors, as claimed by Gopnik in the above quotation. It also explains that more of the field of consciousness will be available to them.

Regarding the self of young children, I will one more time quote Gopnik (2009: 146):

you could say that babies and young children have episodic memory but not autobiographical memory. Although they are very good at remembering specific events in the past, they don't put these events into a single coherent timeline, don't remember how they know about the events, and don't remember their past attitudes toward events.... And they don't have 
a single "inner autobiographer", a self who links their past and present mental states.

Steven Rose (2003: 41) adds that "many childhood memories ... are not linear, not a series of sequential events, but more like pictures, truly 'photographic' memories, even if the photographs come with feels, sounds and smells attached." He calls such memories "eidetic" memories (p. 118), recollected as a series of snapshots, fixed or frozen in time.

It appears, then, that adults preserve memories from their childhood, but that such memories may not be sequentially ordered, and may not even be linked to their sense of self. Remember: "without a sense of self, memories have no meaning" (quoted above); this means: they may be remembered but are not necessarily connected with our sense of self. The question now is: can there be memories of the way the world was experienced in childhood? Does Gopnik's lantern consciousness leave traces that can be recollected, one way or another, by adults?25

I am not aware of research that might give a definite answer to this question. ${ }^{26}$ However, Gopnik compares the experience of babies to the adult experience of travel - preferably to exotic places-, to certain types of meditation, to "other kinds of activities, such as falling in love, hunting, or even mania". "Lantern consciousness is invoked by writers like Virginia Woolf and Emily Dickinson and artists like Henri Cartier-Bresson." (Gopnik 2009: ch. 4). To this list she adds psychedelic drugs (Ananthaswamy 2014). All of these experiences of lantern consciousness, when undergone by adults, leave memories, including memories of the states of awareness in which they were experienced; they are even eminently memorable. It seems safe to conclude that also the lantern consciousness of children can in principle be remembered. However, like Rose's eidetic memories, these impressions may not be part of the autobiographical past that the child will develop in time. The child's lantern consciousness may remain present, frozen in time, as a kind of background awareness that accompanies the adult throughout their life.

25 Note that this kind of recollection has nothing to do with remembering facts, people, things, relationships, and places, which undergoes infantile amnesia (see, e.g., Alberini \& Travaglia 2017). It is part of the theory here presented that memory of the state of awareness does not undergo infantile amnesia.

26 It is not immediately obvious what shape such research could take. Memory of states of awareness does not easily qualify as either "episodic memory" or "semantic memory". I tentatively make the (self-contradictory?) proposal that it is episodic memory without autonoesis (see Tulving 2001; LeDoux 2019: 296 f.). 
We have come to the provisional conclusion that human beings, presumably all of them, ${ }^{27}$ have an intuitive awareness of a state of being very different from what we are used to in daily life. This intuitive awareness is at bottom the nonsequential memory of a state of awareness that we experienced in early childhood; this non-sequential memory does not contribute to our sense of adult identity. Many religious behaviors and beliefs (as well as other behaviors and beliefs) can be understood as resulting from attempts to recover this different state of being, often through the cultivation of mindfulness and absorption. Instances are the following.

Consider prayer. Recent research on prayer as observed in certain Christian churches reveals that there can be more or less skillful pray-ers (i.e., people who pray), that at least some forms of prayer involve skills that can be practiced and developed, and that this skill is absorption. Prayer may allow pray-ers to reach various degrees of mental absorption (Luhrmann 2005; Luhrmann, Nusbaum \& Thisted 2010: 75). In prayer, "when people believe that God will speak to them through their senses, when they have a proclivity for absorption, and when they are trained in absorption by the practice of prayer, these people will report internal sensory experiences with sharper mental-imagery and more sensory overrides". (Luhrmann, Nusbaum \& Thisted 2010: 74). Indeed, "a habit of kataphatic prayer $^{28}$ leads people to report more sensory experiences about God than people listening to lectures on the Gospels ... And that is why inner sense cultivation is important to religion. The great goal of daily practice in an evangelical church in which God speaks back is to teach people to blur the line that the human mind draws between the internal and the external ..." "Inner sense cultivation ... seems to contribute to intense spiritual experience of God". (Luhrmann \& Morgain 2012: 382 ). Researchers have noticed some cognitive effects: "[A] form of prayer practice which uses mental imagery in many sensory modalities, visual above all, increases imagery vividness and (to some extent) alters perceptual accuracy ... Our data have shown that these practices lead to reports of unusual sensory experiences and to reports of unusual sensory experiences associated with the religious ideas which form the content of the practice." (Luhrmann, Nusbaum \& Thisted 2013: 171-172).

27 It would be interesting if people were found who do not have this intuition, presumably because they do not "remember" the state of awareness of early childhood. This issue is briefly discussed in $\S 7$, below.

28 Kataphatic, or affirmative, prayer is to be distinguished from apophatic prayer, in which practitioners disattend to thought and mental imagery (Luhrmann \& Morgain 2012: 362). 
Love and devotion are common means to promote mindfulness and absorption, not only in Christian prayer, but also in the Hindu practice of bhakti, Sufi practices in Islam, and elsewhere. ${ }^{29}$

Ritualized actions, a recent study points out, are "more attention grabbing and more memorable than non-ritualized actions". Certain aspects of ritual "allow for greater allocation of attentional resources". Indeed, "sensorimotor processing of the controlled segmented ritual actions leads to biased attention". "During the performance of a ritual, focusing on the series of action sequences will direct a person's attention to the specific motions and sensory experiences". "[R]ituals can regulate goal-directed behavior ... by heightening attention to the goal context through the experience of segmented, repetitive actions". Rituals may be particularly good at directing attention "because they are inherently compelling and attention grabbing". "[A]dherence to ritual actions limits attention to particular stimuli in the environment"; "focused attention swamps a person's executive systems, leaving little room for personal improvisation or alteration" (Hobson et al. 2018: 263, 265, 268, 273). An earlier study had already stated (Boyer \& Liénard 20o6: 6o6):

... ritualized acts are very different from other routines. However often an individual may perform a ritualized action, it does not seem to become automatic. On the contrary, it remains constrained by high-level cognitive control. Ritualized actions ... require high cognitive control because the rules often apply to familiar actions (e.g., walking, talking, preparing food) and turn them into more difficult task (e.g., walking without treading on the line). This clashes with a commonsense notion that rituals only include actions that one performs "routinely" or "without thinking". Indeed, ... the components of rituals that we called Ritualized Behavior cannot be automatic.

It appears from these quotations that ritual can combine the two practices that correspond to mindfulness and absorption respectively. More than prayer, ritual behavior requires the practitioner to be aware of every single act he or she performs (Ritualized Behavior cannot be automatic).

It is known to the psychology of ritual that the performance of ritual can have a positive emotional effect on its participants. This effect, it is claimed, may be a direct consequence of the mental states in which ritual activities are carried out (Hobson et al. 2018: 265):

29 See, e.g., Hardy 1983/2014; Schimmel 1975. 
One mechanism by which performing rituals may regulate emotion is that the act of performance may direct attention away from one's emotions. During the performance of a ritual, focusing on the series of action sequences will direct a person's attention to the specific motions and sensory experiences. Rituals then can serve as a form of distraction, blocking out possible negative thoughts from entering a person's mind. In line with this thinking, Boyer and Liénard (2006) propose that the physical action units of ritual lead to a swamping of working memory that temporarily reduces anxiety. This attentional demand minimizes anxiety by blocking intrusive thoughts ...

Limited perceptual and cognitive effects have also been observed, but these have not so far been connected with absorption (Nielbo \& Sørensen 2016, esp. p. 319).

There is no reason to disagree with these findings, for they do not contradict the perspective here adopted. Rituals may have these effects, while at the same time being (only partially successful) attempts to recover the different state of consciousness that characterizes early childhood.

Also, religious asceticism can be viewed as an attempt to recover this state of consciousness, but this time mindfulness and absorption play no intermediate role. We saw that in states of deep absorption people do not identify with their activities. The tendency to not identify with one's actions, and with one's body and mind in general, is a recurring theme in asceticism. Often it takes the form of physical and mental immobility. This is most strikingly illustrated by the Indian ascetics who remained motionless for great lengths of time, as it is by the Christian ascetics who did the same (think of the stylites). Refusal to identify with the body also finds expression in the sufferings of the Christian martyrs, elaborately documented in the relevant literature. Puberty initiations in many tribal societies expect the initiands to suffer severe pain with equanimity. ${ }^{30}$ Note that in these cases an implicit belief regarding the nature of one's self is the intermediary that supposedly connects with the state of consciousness looked for. In some cases (such as Brahmanical thought, in India) an explicit belief of the nature of the self takes its place (see below; §6).

30 Bronkhorst 2oola contains many examples (note that I have meanwhile somewhat modified my theoretical take on it). The refusal to identify with one's actions is also found in Sufism (Schimmel 1975: passim, e.g. p. 196). 
We have seen that so-called mystical thought does not necessarily depend on mystical experience: all human beings share an "intuition" that draws them toward "mystical thought". That intuition can be explained, I argue, in terms of an implicit, non-specific, memory (though not memory in the ordinary sense of the word) of the mental state we were in as babies. This state-without sense of self, without a narrative that connects the present with past and future, without language, and without the advanced interpretation of sense impressions that adults apply to them-is only accessible to adults through devices such as mental absorption. Young children have access to it without the help of such devices. Intuition draws adults to such states and inclines them to adopt beliefs and practices that are "felt" to connect with them.

The most striking of these beliefs is the shared conviction that there is a reality different from "ordinary" reality. It is part of most if not all religions, and even non-religious persons may be tempted to believe that "there must be more". It is not confined to those who have had mystical experiences and is not normally looked upon as "mystical". This conviction of a different reality is yet remarkable and demands an explanation. The theory here proposed provides such an explanation.

Only slightly less widespread is the belief that this transcendent reality is inhabited by one or more conscious beings: God, or gods. It has been observed that the "only feature of humans that is always projected onto supernatural beings is the mind". (Boyer 2001: 144; see further Westh 2013). This is not surprising in the light of our theory, which looks upon the belief in a transcendental reality as ultimately based on the intuitive awareness of the way we experienced the world in childhood. ${ }^{31}$ There was always a conscious presence in that experience, a presence that would in due time develop into the notion of self, but had not yet done so at that time. Unsurprisingly, the proximity or even identity of self and God is a recurring theme in many religions. Note however that memories from early childhood do not necessarily predispose to a belief in God, which is after all not part of the child's awareness. This leaves open the question whether Tarzan would believe in God (Banerjee \& Bloom 2013). ${ }^{32}$ The

31 It is certainly no coincidence that the tendency to rely on intuition (rather than on reflection) positively influences one's tendency to believe in God and related things; Shenhav, Rand \& Greene 2011; Pennycook et al. 2012.

32 Indeed, belief in god(s) is not universal in hunter-gatherer societies, and may not have been present in the last common ancestor (LCA) of present-day hunter-gatherers: "Reconstructions are equivocal on whether or not the religion of the LCA of present-day 
theories developed in the cognitive science of religion account for such beliefs (see various chapters in Slone \& McCorkle 2019); our theory finds a place for such entities in transcendental (rather than ordinary) reality.

Many commonly held beliefs go further than this. ${ }^{33} \mathrm{~A}$ set of beliefs that has attracted much attention is the so-called perennial philosophy. Perhaps the best-known representative of this "philosophy" is Aldous Huxley, whose book The Perennial Philosophy first came out in 1944.

What is this perennial philosophy? This is what Huxley says about it (Huxley 1947: 1):

Philosophia perennis - the phrase was coined by Leibniz; ${ }^{34}$ but the thing - the metaphysic that recognizes a divine Reality substantial to the world of things and lives and minds; the psychology that finds in the soul something similar to, or even identical with, divine Reality; the ethic that places man's final end in the knowledge of the immanent and transcendent Ground of all being - the thing is immemorial and universal. Rudiments of the Perennial Philosophy may be found among the traditionary lore of primitive peoples in every region of the world, and in its fully developed forms it has a place in every one of the higher religions.

Shear (1994: 319-320) specifies the "core" of the perennial philosophy in a manner that lays less emphasis on the "divine":

(1) The phenomenal world is the manifestation of a transcendental ground; (2) human beings are capable of attaining immediate knowledge of that ground; (3) in addition to their phenomenal egos, human beings possess a transcendental Self which is of the same or like nature with that transcendental ground; and (4) this identification is life's chief end or purpose.

It is easy to recognize in these summaries two of the features (transcendental reality; transcendental self) that we associated with deep absorption. This

hunter-gatherers included belief in an afterlife, shamanism, ancestor worship, and the concept of a single creator deity, or a high god. Belief in either ancestral spirits or creator deities who remain active in human affairs was not present in ancestral hunter-gatherer societies, according to the reconstructions." (Peoples, Duda \& Marlow 2016: 277).

33 It is to be kept in mind that no attempt will be made to identify or enumerate all the factors that played a role in shaping the following examples. All that counts in the present context is that they illustrate the features of "mystical thought" identified above.

This is not correct: it was coined by Agostino Steuco in 1540; see Bronkhorst 2001: 175 n. 1. 
does not mean that the perennial philosophy is true (as many have claimed), nor that the perennial philosophy is based on mystical experience (as others have claimed). It merely confirms our thesis that human beings have intuitions that predispose them to hold such views. This predisposition, we now think, is based on the background presence in the mind of experience that we all had in childhood.

This predisposition finds expression in other ways as well. Recall that the "real" self does not participate in the activities of body and mind. ${ }^{35}$ It is often conceived of as being non-active by nature; and in religious movements where the transcendental self is believed to be identical with divine reality, this divine reality, too, is thought of as non-active. Here are some examples (Huxley 1947: $\left.5^{2}, 45,117,145,146,22,44,93\right)$ : Ruysbroeck attributes inaction to the Godhead in the following passages: "There is a distinction and differentiation, according to our reason, between God and the Godhead, between action and rest. The fruitful nature of the Persons ever worketh in a living differentiation. But the simple Being of God, according to the nature thereof, is an eternal Rest of God and of all created things." And again: "(In the Reality unitively known by the mystic), we can speak no more of Father, Son and Holy Spirit, nor of any creature, but only one Being, which is the very substance of the Divine Persons. There were we all one before our creation, for this is our super-essence. There the Godhead is in simple essence without activity." Eckhart said: "For in thus breaking through, I perceive what God and I are in common. There I am what I was. There I neither increase nor decrease. For there I am the immovable which moves all things." And again: "The damned are in eternal movement without any mixture of rest; we mortals, who are yet in this pilgrimage, have now movement, now rest.... Only God has repose without movement." Albertus Magnus stated: “... Work to simplify the heart, that being immovable and at peace from any invading vain phantasms, thou mayest always stand fast in the Lord within thee, to that degree as if thy soul had already entered the always present now of eternitythat is, the state of deity....". And again: "[he] becomes immutable and arrives at that true life which is God Himself'.

The idea that the self is by its nature inactive is widespread in Indian thought. And those currents that identify the self with Brahman (primarily Vedanta), attribute inactivity to Brahman as well (e.g., Bronkhorst 2007: passim).

It is easy to add quotations from a variety of religions concerning the inactive nature of God, or of the soul, or of both; there is no need to do so at

35 On a less "deep" level, it appears "that people show a general tendency to conclude that deep inside every individual, there is a 'true self' motivating him or her to behave in ways that are virtuous" (Newman, Bloom \& Knobe 2014). 
present (many examples have been collected in Bronkhorst 2001a). I will however draw attention to some particularly important movements. One of these is Gnosticism as it is depicted in the collection of Gnostic gospels discovered at Nag Hammadi, in Egypt (Robinson 1984). God, and the human soul which is essentially identical with it, are here so often referred to as immovable, immutable, and the like, that those who possess the gnosis are called "the immovable race" (Williams 1985). The theme of inaction as we find it in India is particularly interesting, because its various manifestations are here embedded in a wider theory, the doctrine of karma (e.g., Bronkhorst 1993; 2011). Karma means action, and the doctrine of karma implies that our past actions are responsible for our present state, while our present actions determine our future state. The force of our actions continues, in this way, the cycle of repeated rebirths to which we are subjected. Breaking out of this cycle is only possible by abstaining from further activities, and this is what many Indian ascetics, including Jainas, try to do by practicing immobility. Others believe there is a different way to break the beginningless chain of actions and their results. It consists in the realization that one's true self, one's soul, is by nature inactive. Once a person fully realizes that his true self has nothing whatsoever to do with the activities of their body and mind, the effects of those activities will not affect them anymore, and they will be liberated. Confronted with the question how, then, their body should act, texts like the Bhagavadgita add that one should leave the body to perform the activities prescribed by one's station in life, meanwhile making sure that one does not get involved in these actions.

The theme of inaction is not limited to the nature of the self. Scholars have commented upon the remarkable fact that many tribal societies recognize the existence of a Supreme Being. A noteworthy feature of this Supreme Being in many of its manifestations is its remote and inactive nature (Sullivan 1987). ${ }^{36}$

36 Different researchers propose different answers to the question whether an inactive high god was already part of religion in the remote past. Peoples, Duda \& Marlowe (2016), drawing conclusions from a study of present-day hunter-gatherers about their last common ancestor, observe (p. 272): "The equivocal results based on maximum likelihood and absence according to maximum parsimony for the ancestral state of 'high gods' suggests possible presence of belief in a single creator deity among ancestral hunter-gatherers, albeit one that is not active in human affairs ...". Witzel (2012), who draws conclusions about the remote past from a comparative study of mythologies, states (p. 36o-361): "the Gondwana High God is a deus otiosus who has retreated into heaven and is little occupied with humans and therefore is hardly venerated"; "neither the Gondwana High God, nor the Eurasian (Father) Heaven, nor the Amerindian Great Spirit is a creator god: they do not create the universe or the world, and they leave its establishment to later demiurge deities"; "For the Laurasian case we may ... conclude that the original Pan-Gaean motif of the High God was copied into Laurasian mythology but was reshaped as (Father) Heaven 
The notion of a self that is not involved in the activities of body and mind expresses itself altogether differently in beliefs that are present in many tribal societies (e.g., Hultkrantz 1994). Human beings have here several "souls"; one of these souls, which researchers variously refer to as "free-soul" or "dreamego" or the like, is characterized by the feature of not participating in bodily actions. Often it only has a role to play in situations where the body is motionless: in sleep, trance or unconsciousness (see the surveys by Hultkrantz [1953], Fischer [1965], Hochegger [1965], Paulson [1958]). This particular soul, according to certain researchers, is the principle of life and of consciousness, and the precondition for thought, feeling and will (Fischer 1965: 321, 324).

Evidence

The preceding sections present a theory. What evidence is it based on? Are there ways to test it? Could there be evidence that refutes it?

The theory contains two hypotheses that are used to explain two kinds of phenomena.

The first hypothesis-about the link between absorption and mystical experience - accounts for a number of features that characterize many mystical experiences: access to a different reality, different sense of time, different sense of self, ineffability. The frequent occurrence of these features in mystical experience is not open to doubt. One could however wonder whether they can be explained differently, with the help of a different hypothesis. The possibility of one or more different explanatory hypotheses cannot be discarded-neither here nor in any other area of science. In science, competing hypotheses can often be compared or even confronted, thus allowing the researcher to choose the one that most satisfactorily accounts for the phenomena concerned. Unfortunately, most relevant hypotheses that I am aware of try to explain religious behaviors and beliefs in evolutionary terms, which means that this or that religious practice or belief presumably increases evolutionary fitness. We will see below $(\S 8)$ that in the theory here presented the religious predisposition is a by-product of other characteristics whose contribution to evolutionary fitness is not in doubt. This means that the survival value of resulting behaviors and beliefs, even if it is there, is no more than a bonus that can at best play a subsidiary role in explaining those behaviors and beliefs.

and repositioned to the second age, after initial creation (or 'emergence')". (Gondwana and Laurasia are technical terms introduced by Witzel to refer to different categories of myths that are historically linked to different geographical regions.). 
In short, those alternative explanatory hypotheses are not in conflict with the one here presented; they are not competing hypotheses. Without competing hypotheses, there is nothing to compare.

Statistical testing of the hypothesis might be conceivable if one could compare depth of absorption with frequency of experiential features. At present no such testing seems possible, the main reason being that no objective scale measuring depth of absorption - by which I mean: based on neurophysiological measurements-is available (see note 13, above). (I consider developing such a scale a desideratum.)

The second hypothesis-regarding the memory (though not remembered memory) that we preserve of the manner in which young children experience the world-explains the curious phenomenon that the features mentioned above often appear in the discourse and behavior of people who have not had mystical experiences. As curious as it is, this phenomenon has not so far attracted scholarly attention. The explanation here proposed, our second hypothesis, is necessarily tentative. It is based on recent developments in child psychology, which have not yet stood the test of time. On the other hand, it provides a simple explanation of a most remarkable phenomenon that may be a cornerstone of religious behavior and belief.

Might this phenomenon be explained by alternative hypotheses? As in all other branches of science, there is no way to rule this out. However, to the best of my knowledge no such alternatives are available, for the simple reason that the present article focuses on features that have not attracted scholarly attention so far.

One could imagine that the second hypothesis could be tested in individuals whose childhood memory of states of awareness is deficient. ${ }^{37}$ What would their "spiritual" life look like? Would they be free from the tendency to believe in a higher reality? Questions like these are premature, because it has not even been established as yet that anyone has memories from earliest childhood that preserve the manner in which the child experienced the world. This, as I pointed out in $\S 4$, is an issue clarity about which would be most welcome.

It is possible (though perhaps not likely) that future research in child psychology will show that young children do not experience the world in the manner described by Gopnik and her colleagues. It is also conceivable that research will demonstrate that these early forms of experience leave no traces, in which case they cannot affect adults. If so, our second hypothesis will have to be modified or abandoned.

37 Ordinary childhood amnesia concerns contents, not states of awareness. The two should not be confused. 
The two hypotheses combined maintain (i) that human beings try to reestablish mental states they had in early childhood, and (ii) that they do so by means of practices and beliefs in which mental absorption plays a central role. The theory is of course preliminary, but this cannot be held against it, for all scientific results are preliminary, open to future improvements-or rejection. ${ }^{38}$ What counts in its favor is that it makes coherent sense of many behaviors and beliefs (many of which commonly considered religious). Another point in its favor, I would like to add, is its elegance: it does not need, or presuppose, complicated structures, nor does it postulate unspecified mutations in the genome related to this or that behavior or belief.

\section{8}

\section{Conclusion}

At the end of his book Mysticism and Philosophy, W. T. Stace (1960: 343) discussed the claim "that mysticism is ultimately the source and essence of all religion". He rejected this claim for the following reason: "We shall have to maintain that mystical consciousness is latent in all men but is in most men submerged below the surface of consciousness.... its influences appear [in the upper consciousness] in the form of religious impulses. And these in turn will give rise to the intellectual impulses which are the various creeds." Stace thought that "difficulties this kind of view has to meet, ... though perhaps not insuperable, are very great".

We have come to a position that is close to the one that Stace considered beset with "very great difficulties". We agree with him that mysticism is not "ultimately the source and essence of all religion", certainly not in any straightforward manner. But our reflections do justify the belief that something like mystical consciousness is latently present in all of us "below the surface of consciousness"; or rather: in our memory. Indeed, this so-called mystical consciousness is the way we experienced the world and ourselves in early childhood. We do not remember this awareness the way we remember things in later childhood and as adults. But it is remembered none-the-less, in a nonsequential and to some extent impersonal manner, which explains that we "recognize" experiences and ideas that take us closer to it. And these are the experiences and ideas that frequently become part of religion in its multiple manifestations.

38 "Rather than closing down a question, publication is intended to be a red flag to bullish colleagues" (Cox \& Cohen 2017: 23). 
Let it be clear that this latent mystical consciousness is not "ultimately the source and essence of all religion" either. Yes, it accounts for many features that find expression in numerous religions, but it does not account for countless other features. Not even the belief in God or gods is fully accounted for, as we have seen. However, the theory here proposed may be thought of as a coat rack that may be particularly well suited to provide place for such beliefs.

One important question remains. It may be true that certain religious behaviors and beliefs bring evolutionary benefits, the evolutionary benefits of certain other religious behaviors and beliefs are far from evident, and some of them are clearly "counter-reproductive". Indeed, "[f]rom an evolutionary standpoint, it's odd that natural selection wouldn't have forestalled the emergence of such an expensive ensemble of brain and body behaviors" (Atran 2002: 264). Odd it may be, but some harmful religious practices (harmful from an evolutionary point of view, such as initiations that physically harm the initiands) may have been around long enough to raise the question why they have not been selected away (e.g., Owens \& Hayden 1997; McCauley, Maxwell \& Collard 2018). Can we seriously maintain that we have an inherited predisposition to ritual, for example? ${ }^{39}$ If not, how then do we account for these and other religious practices and beliefs?

The position here taken is that we are not genetically programmed to engage in religious practices or to accept religious beliefs. These are rather by-products of certain other features: the capacity to concentrate and the acquisition of language. We would not survive without the faculty of concentration or attention, yet it is this faculty that points the way toward a state of awareness to which we have no longer access as adults, but which we "remember". The evolutionary significance of language cannot be doubted. The acquisition of language creates an extensive web of associations that separates infantile from adult awareness. ${ }^{40}$ Deep absorption is the means accessible to some of us to pierce through this web. The combination of these two-the faculty of concentration and the acquisition of language-made us susceptible to religious practices and beliefs, in the manner explained above.

Absence of language explains that animals different from humans have no communicable religious beliefs (to the best of our knowledge), but not just that. This same absence may also explain that animals do not appear to engage in religious practices. This conclusion has to be tentative for the time being,

39 So, e.g., Michaels 2016: 284: "As rituals are found everywhere and in every society, one must indeed assume an inherited predisposition to ritual—an ability that seeks culturally varying forms of expression."

For a detailed study of this web, see Bronkhorst 2010 / 2012a. 
especially since Jane Goodall understands certain chimpanzee dances as having spiritual significance (see https://www.youtube.com/watch?v=jjQCZClpaaY; further Kühl et al. 2016; Schaefer 2015). Her suggestion is not in conflict with the theory here presented, but it is highly unlikely that religious practices (if at all present) will play a role of much significance in animals that do not use language.

\section{9}

\section{Questions that Remain}

The preceding pages have shown that there are reasons to think that many religious practices and beliefs (and no doubt many other practices and beliefs) find an explanation in the assumption that human beings (often unknowingly) attempt to recover a state of awareness that belongs to their early childhood. This, however, raises new questions. The present section will formulate some of these, without making claims as to how they should be answered. At best, it will share some speculative thoughts that must be taken for what they are worth.

Why should people make attempts to recover an earlier state of awareness? What is behind this drive that ultimately finds expression in religious practices and beliefs (and no doubt elsewhere)? Preceding sections introduced the notion of intuition and explained what we mean by it. We intuit that there is a "higher" reality behind our everyday world, and we intuit that certain activities get us closer to that reality. But why would we want to know that reality, and why would we want to get closer to it? These questions have not so far been addressed.

We can be brief about religious beliefs. It is not surprising that people show a preference for beliefs that somehow "feel" more real than beliefs that do not evoke this feeling. ${ }^{41}$ We saw that states of deep absorption feel more real than ordinary awareness for a simple reason: they are less interpreted. This feeling apparently accompanies, even in ordinary states of mind, beliefs that are somehow related to the intuited memory of the state of young children.

This does not yet explain the tendency to engage in religious practices. What is the motivation behind these? Why should people make attempts to recover the state of consciousness of early childhood?

41 There is a discussion around the question to what extent people really believe religious beliefs; see Boudry \& Coyne 2016, contra Van Leeuwen 2014; further Boyer 2013; Bronkhorst 2016. 
There may be different answers for different practices. We have seen that those who experience states of deep absorption tend to consider those states as somehow more real, or as opening up a reality that is "higher", more "real", than ordinary reality. Ritual, by deepening the level of absorption, provides access, if ever so limited, to that higher reality. It is not infrequently used to anchor ordinary human transactions into that higher reality, presumably making them irreversible. The wedding ritual goes in this way beyond the promises that are exchanged; being grounded in that higher reality, these promises cannot easily be broken. Numerous other rituals serve a similar purpose: they "sanctify" human transactions or relations in a manner that makes them irreversible. Sacrifices, for example, may give a transcendent dimension to relationships of inferiority and superiority. When we take this "practical" side of rituals into consideration, the urge to perform them looks less mysterious. ${ }^{42}$

However, no such "practical" side is obvious in the case of asceticism and martyrdom (unless, of course, one takes literally the belief systems in which they are integrated). We saw that the implicit notion of self that inspires many forms of asceticism - the conviction that one is different from one's body and one's actions - brings back the awareness of early childhood in which there is no developed sense of self. This does not however explain why certain people seek to confront the consequences of this notion in situations of often selfinflicted or solicited pains and tortures. ${ }^{43}$

This issue cannot be dealt with without discussing a question that I have so far carefully avoided. States of deep absorption are frequently accompanied by feelings of bliss, even ecstasy. How does that fit in?

I am not sure why deep absorption should give rise to intense pleasure. ${ }^{44}$ However, there is one factor that clearly plays a role. Deep absorption goes hand in hand with deep relaxation. This is even true of less deep forms of absorption, such as hypnotic trance and flow, even prayer. ${ }^{45}$ This fits in well into the theory here presented. We saw that deep absorption requires an extension of the realm of the explicit system of mental functioning at the expense of the implicit system. The implicit system is responsible for the activities and

42 This issue has been dealt with at length in Bronkhorst 2012.

43 It may however make such people susceptible to psychological manipulation; cf. Pinker 2012: §2.

44 It is possible that the focusing aspect of absorption, here ignored (see note 3 , above), plays a role.

45 For hypnosis, see Edmonston 1979: 455: "That neutral hypnosis and relaxation are equated is not an artifact of history, but a statement of a persistent finding in the data." For prayer, see Elkins, Anchor \& Sandler 1979. 
behaviors that take place without conscious supervision. This includes habits and vigilance. To maintain the latter, we preserve a certain amount of bodily tension (including muscle tone) that we cannot reduce until and unless we temporarily recuperate part of the implicit system for the explicit system; i.e. until and unless we reach a state of deep enough absorption. Reduced tension no doubt gives rise to pleasure, but I do not know whether reduced tension, even greatly reduced tension, suffices to explain the extreme pleasure that is so often claimed to accompany deep absorption. ${ }^{46}$

Clearly asceticism and martyrdom do not give rise to pleasure. Nor is there reason to assume that ascetics and martyrs pass much of their time (or any) in states of deep absorption. Ascetics and martyrs do not act the way they do because it gives them pleasure. It does not, at any rate not in the short term. Many of them, on the other hand, believe that it will do so in the long term. Does this explain their behavior? Are they looking for delayed gratification? Is their behavior of the kind that allows certain children not to eat the marshmallow that is put in front of them (Mischel 2014)? Perhaps they do, but I fail to convince myself that this can count as a fully satisfactory explanation. Is there some more general principle involved beyond the beliefs that ascetics and martyrs inherit from their specific religious or cultural traditions?

It seems relevant to remember that the transition from child consciousness to adult consciousness is a long and slow process. This process is unavoidable in any normal development into adulthood. However, is there perhaps a "counter current" that accompanies this process all along but works against it? Axel Michaels has argued in some publications $(1997 ; 2006 ; 2011)$ that anxiety (Angst) is inseparable from religion; the two share a symbiotic relationship. ${ }^{47}$ Is it possible that anxiety is the force that works against the process of becoming adult, that pushes people to find a "way back" through religious practice? Assuming the central importance of anxiety would have the advantage of explaining many forms of religious behavior, including those (such as asceticism) that look problematic at first sight. For the time being, I prefer not to commit myself. ${ }^{48}$

46 See Birbaumer's account of taking curare, which completely relaxes muscles (Birbaumer \& Zittlau 2018: Loc 1513).

47 It seems that the specific form of anxiety that is death anxiety and religion do not share such a relationship; Jong \& Halberstadt 2018.

48 Sterelny (2018: 408) observes: "Existential terror seems to have a much deeper history than religion, and hence does not explain religion." This does not exclude that existential terror may have played a role in the development of religion. 


\section{Appendix 1: Reality}

Deep absorption, we saw, can give access to an experience that may be felt as giving access to a reality different from the reality experienced in ordinary states of mind; this alternative reality may be experienced as more real. Philosophers since Plato have argued that our senses have no access to reality as it is. Immanuel Kant's (17241804) Critique of Pure Reason (Kant 1781/1998) updated this idea, and most recently Donald Hoffman (2019) has given it a different twist. In its most recent manifestation, it takes the form that Darwinian evolution has selected in favor of fitness, not truth. As a result we supposedly have no access whatsoever to reality: our sense organs present us with fitness payoffs, i.e., what is useful for survival and procreation, not with reality.

In this paper there is no need to take position with respect to this theory. What counts is that the "reality" to which deep absorption may be believed to give access has nothing to do with Kantian or neo-Kantian reality. Deep absorption may conceivably convince its subjects that what they experience is more real than what they experience in different mental states, but this should not be confused with access to the reality that, according to Kantian and neo-Kantian theory, hides behind our perceptions, which lies "beyond the interface". 49

\section{Appendix 2: Meditation in the History of Buddhism}

There is a common misunderstanding about meditation as it has supposedly been practiced throughout the history of Buddhism. Robert Sharf has convincingly argued (1995) that it is far from clear how many Buddhists actually meditated in historical times, perhaps far fewer than is often supposed, and that much the same is true even of those who wrote about meditational states: it is virtually unheard of in classical Buddhist literature that an author speaks about his or her own meditational experiences. This impression is confirmed by the limited role that meditation plays in a number of contemporary Buddhist traditions. About Tibetan Buddhism, George Dreyfus states (2003: 168): "But how many monks meditate in the large Tibetan scholastic centers? Not many, it appeared to me." And about Korean Buddhist, Robert Buswell observes (1992: 159): "the hwadu [which corresponds more or less to the Japanese koan, Jв] is not intended to generate a state of samādhi ..., but a state in which both the calmness of samādhi and the perspicuity of prajñ $\bar{a}$ are maintained. This ... may account for the reason why I knew few Sŏn monks to have the ability in the deep meditative

49 A reality that for Kant is inaccessible but consists of conscious agents according to Hoffman. 
absorptions, or dhyānas (Pali jhāna), that I had encountered before among the forest monks of Thailand." About the authors of the Mülasarvāstivāda-vinaya, a massive Buddhist text composed in India during the early centuries of the Common Era, Gregory Schopen (2000: 104 [15]) writes: "Unlike modern scholars, these 'good' monks did not have much good to say about monks who did engage in asceticism, meditation, and doctrinal learning. If they mention them at all—and they do so infrequently-it is almost always with a tone of marked ambivalence, if not actual ridicule. Ascetic monks, meditating monks, and learned monks appear in our Vinaya by and large only as slightly ridiculous characters in unedifying, sardonic, and funny stories or as nasty customers that 'good' monks do not want to spend much time around." Attributing states of deep absorption to the individual authors of Buddhist texts is as risky as doing so in the case of Western mystical literature.

\section{References}

Alberini, Cristina M. and Alessio Travaglia (2017). Infantile amnesia: A critical period of learning to learn and remember. The Journal of Neuroscience 37(24): 5783-5795.

Ananthaswamy, Anil (2014). Trippy tots: How to see the world as a baby. New Scientist 2983 (21 August 2014).

Antinori, Anna; Carter, L. Olivia, and Luke D. Smillie (2017): Seeing it both ways: Openness to experience and binocular rivalry suppression. Journal of Research in Personality 68: 15-22.

Atran, Scott (2002). In Gods We Trust: The Evolutionary Landscape of Religion. Oxford: Oxford University Press.

Austin, James H. (1998). Zen and the Brain. Toward an Understanding of Meditation and Consciousness. Cambridge, Massachusetts \& London, England: MIT Press.

Austin, James H. (2006). Zen-Brain Reflections: Reviewing Recent Developments in Meditation and States of Consciousness. Cambridge, Massachusetts \& London, England: MIT Press.

Baier, Karl (2019). Meditation and contemplation: Two basic types of spiritual exercises within Western European Christianity. In Elizabeth Harris and John O'Grady (eds.): Meditation in Buddhist-Christian Encounter. A critical analysis, 59-110. EOsEditions of Sankt Ottilien.

Banerjee, Konika, and Paul Bloom (2013). Would Tarzan believe in God? Conditions for the emergence of religious belief. Trends in Cognitive Sciences 17(1): 7-8.

Barrett, Lisa Feldman (2017). How Emotions are Made. The Secret Life of the Brain. London: Macmillan.

Berlin, Heather A. (2011). The neural basis of the dynamic unconscious. Neuropsychoanalysis 13(1): 5-31. 
Birbaumer, Niels, and Jörg Zittlau (2018). Thinking is Overrated. Empty Brain-happy brain. Translated by David Shaw. Melbourne-London: Scribe. (e-book).

Blom, Jan Dirk, and Iris E. C. Sommer (eds.) (2012). Hallucinations. Research and Practice. Berlin: Springer.

Bodhi, Bhikkhu (1995). The Middle Length Discourses of the Buddha: A New Translation of the Majjhima Nikaya. Original translation by Bhikkhu Nanamoli, translation edited and revised by Bhikkhu Bodhi. Boston: Wisdom Publications.

Boudry, Maarten, Stefaan Blancke, and Massimo Pigliucci (2015). What makes weird beliefs thrive? The epidemiology of pseudoscience. Philosophical Psychology 28(8): 1177-1198.

Boudry, Maarten, and Johan Braeckman (2012). How convenient! The epistemic rationale of self-validating belief systems. Philosophical Psychology 25(3): 341-364.

Boudry, Maarten, and Jerry Coyne (2016). Disbelief in belief: On the cognitive status of supernatural beliefs. Philosophical Psychology 29(4): 601-615.

Boyer, Pascal (2001). Religion Explained: The Evolutionary Origins of Religious Thought. New York: Basic Books. English edition: Religion Explained: The Human Instincts that Fashion Gods, Spirits and Ancestors. London, Sydney, etc.: W. Heinemann.

Boyer, Pascal (2013). Why 'belief' is hard work. Implications of Tanya Luhrmann's When God talks back. HAU: Journal of Ethnographic Theory 3(3): 349-357.

Boyer, Pascal, and Pierre Liénard (2006). Why ritualized behavior? Precaution systems and action parsing in developmental, pathological and cultural rituals. Behavioral and Brain Sciences 29: 595-65o.

Bronkhorst, Johannes (1993). The Two Traditions of Meditation in Ancient India. Second edition. Delhi: Motilal Banarsidass.

Bronkhorst, Johannes (2001). The perennial philosophy and the law of karma. In C. C. Barfoot (ed.), Aldous Huxley between East and West, 175-189. Amsterdam and New York: Rodopi.

Bronkhorst, Johannes (2001a). Asceticism, religion and biological evolution. Method \& Theory in the Study of Religion 13: 374-418.

Bronkhorst, Johannes (2007). Greater Magadha. Studies in the Culture of Early India. Leiden: Brill.

Bronkhorst, Johannes (2009). Buddhist Teaching in India. Boston:Wisdom Publications. Bronkhorst, Johannes (2010). Ritual, holophrastic utterances, and the symbolic mind. In Axel Michaels and Anand Mishra (eds.), Ritual Dynamics and the Science of Ritual. Volume I: Grammar and morphologies of ritual practices in Asia, 159-202. Wiesbaden: Harrassowitz.

Bronkhorst, Johannes (2011). Karma. Honolulu: University of Hawai'i Press.

Bronkhorst, Johannes (2012). Rites without symbols. Method \& Theory in the Study of Religion 24: 236-266. 
Bronkhorst, Johannes (2012a): The symbolic mind. = Bronkhorst 2012b: 9-69. (An updated version of Bronkhorst 2010.)

Bronkhorst, Johannes (2012b): Absorption. Human Nature and Buddhist Liberation. Paris: UniversityMedia.

Bronkhorst, Johannes (2016). What did Indian philosophers believe? In Piotr Balcerowicz (ed.), Logic and Belief in Indian Philosophy, 2nd rev. ed., 19-44. Online at: https://ia6o15o6.us.archive.org/8/items/logicandbeliefinindianphilosophy2016/ Logic_and_Belief_in_Indian_Philosophy_2016.pdf

Bronkhorst, Johannes (2017). Can religion be explained? The role of absorption in various religious phenomena. Method and Theory in the Study of Religion 29:1-30.

Bronkhorst, Johannes (forthcoming). Buddhist meditation, flow and ritual. In Anand Singh (ed.), Rethinking Buddhism: Text, context and interpretations. Delhi: Primus Publishers.

Buswell, Robert E. (1992). The Zen Monastic Experience: Buddhist Practice in Contemporary Korea. Princeton: Princeton University Press.

Chabris, Christopher, and Daniel Simons (2010). The Invisible Gorilla and Other Ways Our Intuition Deceives Us. London: HarperCollins.

Chou, Wei-Lun, and Su-Ling Yeh (2012). Object-based attention occurs regardless of object awareness. Psychonomic Bulletin \& Review 19(2): 225-231.

Cox, Brian, and Andrew Cohen (2017). Forces of Nature. London: William Collins.

Craig, A. D. (2009). How do you feel—now? The anterior insula and human awareness. Nature Reviews, Neuroscience 10(1): 59-70.

Craig, A. D. (2015). How Do You Feel? An Interoceptive Moment with Your Neurobiological Self. Princeton: Princeton University Press.

Damasio, Antonio (2010). Self Comes to Mind: Constructing the Conscious Brain. New York: Pantheon Books.

Dehaene, Stanislas, and Jean-Pierre Changeux (2011). Experimental and theoretical approaches to conscious processing. Neuron $7 \mathrm{O}(3)$ : 200-227.

Dennett, Daniel C. (1991). Consciousness Explained. Boston: Little, Brown and Company.

Dennett, Daniel C. (2017). From Bacteria to Bach and Back. The Evolution of Minds. London: Allen Lane.

Desimone, Robert, and John Duncan (1995). Neural mechanisms of selective visual attention. Annual Review of Neuroscience 18: 193-222.

Dietrich, Arne, and Hilde Haider (2017). A neurocognitive framework for human creative thought. Frontiers in Psychology 7:2078. doi: 10.3389/fpsyg.2016.02078.

Dreyfus, Georges B. J. (2003). The Sound of Two Hands Clapping. Berkeley: University of California Press.

Elkins, David, Kenneth N. Anchor, and Howard M. Sandler (1979). Relaxation training and prayer behavior as tension reduction techniques. Behavioral Engineering 5(3): $81-87$. 
Edmonston, William E. (1979). The effects of neutral hypnosis on conditioned responses: Implications for hypnosis as relaxation. In Erika Fromm \& Ronald E. Shor (eds.), Hypnosis: Research, Developments and Perspectives, 415-455. London: Routledge.

Everett, Caleb (2017). Numbers and the Making of Us. Cambridge, MA: Harvard University Press.

Eysenck, Michael W. (1982). Attention and Arousal. Cognition and Performance. Heidelberg: Springer.

Feinberg, Todd E., and John M. Mallatt (2016). The Ancient Origins of Consciousness. How the Brain Created Experience. Cambridge, MA: MIT Press (Kindle edition).

Fischer, Hans (1965). Studien über Seelenvorstellungen in Ozeanien. München: Klaus Renner.

Franco, Eli (2018). On the arising of philosophical theories from spiritual practice. In Oliver von Criegern, Gudrun Melzer, and Johannes Schneider (eds.), Festschrift für Jens-Uwe Hartmann zum 65. Geburtstag, 113-126. Wien: Arbeitskreis für Tibetische und Buddhistische Studien Universität Wien.

Frith, Chris (2007). Making up the Mind. How the Brain Creates Our Mental World. Oxford: Blackwell.

Geertz, Armin W. (ed.) (2013). Origins of Religion, Cognition and Culture. Durham: Acumen.

Gopnik, A. (2009). The Philosophical Baby. What Children's Minds Tell Us About Truth, Love, and the Meaning of Life. New York: Farrar, Straus and Giroux.

Gorelik, Gregory (2016): The evolution of transcendence. Evolutionary Psychological Science 2: 287-307.

Gorelik, Gregory, and Todd K. Shackelford (2017). What is transcendence, how did it evolve, and is it beneficial? Religion, Brain \& Behavior 7(4):361-365

Hackett, Jeremiah M. (2013). A Companion to Meister Eckhart. Leiden: Brill.

Hardy, Alister (1979). The Spiritual Nature of Man. A Study of Contemporary Religious Experience. Oxford: Clarendon Press.

Hardy, Friedhelm (1983/2014): Viraha Bhakti. The Early History of Kṛṣna Devotion. Delhi: Motilal Banarsidass.

Hay, David (1990). Religious Experience Today. Studying the Facts. London: Mowbray.

Hobson, Nicholas M., Juliana Schroeder, Jane L Risen, Dimitris Xygalatas, and Michael Inzlicht (2018). The psychology of rituals: An integrative review and process-based framework. Personality and Social Psychology Review 22(3): 26o-284.

Hochegger, Hermann (1965). Die Vorstellungen von 'Seele' und Totengeist bei afrikanischen Völkern. Anthropos 6o: 273-339.

Hoffman, Donald D. (1998). Visual Intelligence. How we Create What We See. New York: W. W. Norton.

Hoffman, Donald D. (2012). The construction of visual reality. = Blom \& Sommer 2012: 7-15. 
Hoffman, Donald (2019). The Case Against Reality. Why Evolution Hid the Truth from Our Eyes. New York: W. W. Norton.

Hofstadter, Douglas, and Emmanuel Sander (2013). Surfaces and Essences: Analogy as the Fuel and Fire of Thinking. New York: Basic Books.

Hood, Bruce (2012). The Self Illusion. London: Constable.

Hultkrantz, Åke (1953). Conceptions of the Soul Among North American Indians. A Study in Religious Ethnology. Stockholm: The Ethnographical Museum of Sweden. (Cp. Hultkrantz 1997.)

Hultkrantz, Åke (1994). Gnostic parallels in America? A problem of identity, diffusion

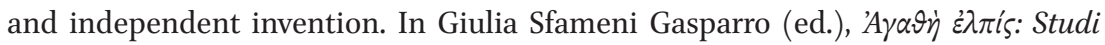
Storico-Religiosi in Onore di Ugo Bianchi, 463-478. Roma: "L'Erma" di Bretschneider.

Hultkrantz, Åke (1997). Soul and Native Americans. Edited with a foreword by Robert Holland. Woodstock: Spring Publications. (Reduced and edited version of Hultkrantz, 1953.)

Huxley, Aldous (1947). The Perennial Philosophy. London: Chatto \& Windus.

James, William (1902). The Varieties of Religious Experience. Reprint: Fount Paperbacks, Glasgow, 1979 .

Jong, Jonathan, and Jamin Halberstadt (2018). Death Anxiety and Religious Belief. An Existential Psychology of Religion. London: Bloomsbury.

Kant, Immanuel (1781/1998). Critique of Pure Reason. Translated and edited by Paul Guyer and Allen W. Wood. Cambridge: Cambridge University Press.

Kimmel, Monica L. (2008). Interpreting Mysticism. An Evaluation of Steven T. Katz's Argument Against a Common Core in Mysticism and Mystical Experience. Doctoral thesis, University of Gothenburg, Department of Religious Studies, Theology and Classical Philology.

Koch, Christof (2019). The Feeling of Life Itself. Why Consciousness is Widespread but Can't be Computed. Cambridge, MA: MIT Press.

Kühl, Hjalmar S. et al. (9o authors) (2016). Chimpanzee accumulative stone throwing. Scientific Reports 6: 22219 (DOI: 10.1038/srep22219)

LeDoux, Joseph (2019). The Deep History of Ourselves. The Four-Billion-Year Story of How We Got Conscious Brains. New York: Viking.

Leech, Robert, Denis Mareschal, and Richard P. Cooper (2008). Analogy as relational priming: A developmental and computational perspective on the origins of a complex cognitive skill. Behavioral and Brain Sciences 31: 357-414.

Lotto, Beau (2017). Deviate. The Creative Power of Transforming Your Perception. London: Weidenfeld \& Nicolson.

Luhrmann, T. M. (2005). The art of hearing God: Absorption, dissociation, and contemporary American spirituality. Spiritus: A Journal of Christian Spirituality 5(2): 133-157.

Luhrmann, T. M., and Rachel Morgain (2012). Prayer as inner sense cultivation: An attentional learning theory of spiritual experience. ETHOS 4O(4): 359-389. 
Luhrmann, T. M., Howard Nusbaum, and Ronald Thisted (2010). The absorption hypothesis: learning to hear God in Evangelical Christianity. American Anthropologist 112(1): 66-78.

Luhrmann, T. M., Howard Nusbaum, and Ronald Thisted (2013). 'Lord, teach us to pray': Prayer practice affects cognitive processing. Journal of Cognition and Culture 13: 159-177.

Magee, Glenn Alexander (ed.) (2016). The Cambridge Handbook of Western Mysticism and Esotericism. Cambridge: Cambridge University Press.

McCauley, Brea, David Maxwell, and Mark Collard (2018). A cross-cultural perspective on Upper Palaeolithic hand images with missing phalanges. Journal of Paleolithic Archaeology 1(4): 314-333.

Michaels, Axel (1997). Religionen und der neurobiologische Primat von Angst. In F. Stolz (ed.), Homo naturaliter religiosus?, 91-136. Bern: Peter Lang.

Michaels, Axel (2006). Religionen ohne Gottesfurcht? Angstbewältigung im Religionsvergleich. In Jan Baldewien and Hans Erich Loos (ed.), “Angst essen Seele auf"-Vom Umgang mit den Ängsten, 44-68. Karlsruhe: Evangelische Akademie Baden.

Michaels, Axel (2011). Religionen und Angst: religionswissenschaftliche Aspekte. Jahresheft der Theologischen Fakultät der Universität Heidelberg 6 (2010/11): 14-32.

Michaels, Axel (2016). Homo Ritualis. Hindu Ritual and Its Significance for Ritual Theory. Oxford: Oxford University Press.

Milem, Bruce (2016). Medieval Christian mysticism. = Magee 2016: 107-117.

Mischel, Walter (2014). The Marshmallow Test: Mastering Self-Control. New York: Little, Brown and Company.

Mordvintsev, Alexander, Christopher Olah, and Mike Tyke (2015). Inceptionism: going deeper into neural networks. Google Research Blog, June 17, 2015.

The Mystical Experience Registry. http://www.bodysoulandspirit.net/mystical _experiences/

Newman, George E., Paul Bloom, and Joshua Knobe (2014). Value judgments and the true self. Personality and Social Psychology Bulletin 40(2): 203-216.

Nielbo, K. L., and J. Sørensen (2016). Attentional resource allocation and cultural modulation in a computational model of ritualized behavior. Religion, Brain \& Behavior 6(4): 318-335.

Nisbett, Richard E. (2003). The Geography of Thought. How Asians and Westerners Think Differently ... And Why. New York: Free Press.

Ott, Ulrich (2007). States of absorption: in search of neurobiological foundations. In Graham A.Jamieson (ed.), Hypnosis and Conscious States: The Cognitive Neuroscience Perspective, 257-2700. Oxford: Oxford University Press. 
Owens, D'Ann, and Brian Hayden (1997). Prehistoric rites of passage: A comparative study of transegalitarian hunter-gatherers. Journal of Anthropological Archaeology 16: 121-161.

Paulson, Ivar (1958). Die primitiven Seelenvorstellungen der nordeurasischen Völker. Stockholm: The Ethnographical Museum of Sweden.

Peoples, Hervey C., Pavel Duda, and Frank Marlowe (2016). Hunter-gatherers and the origins of religion. Human Nature 27(3): 261-282.

Pennycook, Gordon James Allan Cheyne, Paul Seli, Derek J. Koehler, and Jonathan A. Fugelsang (2012). Analytic cognitive style predicts religious and paranormal belief. Cognition 123(3): 335-346.

Pinker, Steven (2012). The false allure of group selection. Edge [Internet] 2012 June 18. Online at: https://www.edge.org/conversation/steven_pinker-the-false-allure -of-group-selection

Robinson, James M. (ed.) (1984). The Nag Hammadi Library in English. Second edition. Leiden: Brill.

Rose, Steven (2003). The Making of Memory. From Molecules to Mind. Revised edition. London: Vintage.

Schaefer, Donovan O. (2015). Religious Affects. Animality, Evolution, and Power. Durham: Duke University Press.

Schimmel, Annemarie (1975): Mystical Dimensions of Islam. Chapel Hill: University of North Carolina Press.

Schmithausen, Lambert (1981): On some aspects of descriptions or theories of 'liberating insight' and 'enlightenment' in early Buddhism. In Klaus Bruhn \& Albrecht Wezler (eds), Studien zum Jainismus und Buddhismus (Gedenkschrift für Ludwig Alsdorf), 199-25o. Wiesbaden.

Schopen, Gregory (2000). The good monk and his money in a Buddhist monasticism of 'the Mahāyāna period'. The Eastern Buddhist n.s. 32(1): 85-105. Reprint with stylistic changes: Schopen 2004:1-18.

Schopen, Gregory (2004): Buddhist Monks and Business Matters: Still more papers on monastic Buddhism in India. Honolulu: University of Hawai'i Press.

Searle, John R. (2010). Making the Social World. The Structure of Human Civilization. Oxford: Oxford University Press.

Searle, John R. (2015). Seeing Things as They Are: A Theory of Perception. Oxford: Oxford University Press.

Sharf, Robert H. (1995). Buddhist modernism and the rhetoric of meditative experience. Numen 42: 228-283.

Shear, Jonathan (1994). On mystical experiences as support for the perennial philosophy. Journal of the American Academy of Religion 62(2): 319-342.

Shenhav, Amitai, David G Rand, and Joshua D. Greene (2012). Divine intuition: Cognitive style influences belief in God.Journal of Experimental Psychology: General $141(3): 423-428$. 
Shi, Ran, Louise Sharpe, and Maree Abbott (2019). A meta-analysis of the relationship between anxiety and attentional control. Clinical Psychology Review 72, August 2019, 101754. https://doi.org/10.1016/j.cpr.2019.101754

Sil, Narasingha P. (1991). Rāmakrșṇa Paramahaṃsa. A Psychological Profile. Leiden: Brill.

Slone, D. Jason, and William M. McCorkle (eds.) (2019). The Cognitive Science of Religion. A Methodological Introduction to Key Empirical Studies. London: Bloomsbury.

Spiegel, Herbert, and David Spiegel (2004). Trance and Treatment. Clinical Uses of Hypnosis. Second edition. Washington, DC: American Psychiatric Publishing.

Stace, W. T. (1960). Mysticism and Philosophy. London: MacMillan.

Sterelny, Kim (2018). Religion re-explained. Religion, Brain \& Behavior 8(4): 406-46o.

Sullivan, Lawrence E. (1987). Supreme beings. In Mircea Eliade (ed.), The Encyclopedia of Religion, vol. 14, 166-181. New York: Macmillan,.

Sweeny, Timothy D., Nicole Wurnitsch, Alison Gopnik, and David Whitney (2015). Ensemble perception of size in 4-5-year-old children. Developmental Science 18(4): 556-568.

Tart, Charles T. (1983). States of Consciousness. New York: Dutton.

Taves, Ann (2009). Religious Experience Reconsidered: A Building-Block Approach to the Study of Religion and Other Special Things. Princeton: Princeton University Press.

Tulving, Endel (2001). Origin of autonoesis in episodic memory. In Henry L. Roediger III, James S. Nairne, Ian Neath, and Aimée M. Surprenant (eds.), The Nature of Remembering. Essays in honor of Robert G. Crowder, 17-34. Washington: American Psychological Association.

Underhill, Evelyn (1911). Mysticism. A Study in the Nature and Development of Man's Spiritual Consciousness. Reprint: Methuen \& Co., London, 1949.

Van Leeuwen, Neil (2014). Religious credence is not factual belief. Cognition 133(3): 698-715.

Vergauwe, Evie, Pierre Barrouillet, and Valérie Camos (2010). Do mental processes share a domain-general resource? Psychological Science 21: 384-39o.

Watzl, Sebastian (2011). The nature of attention. Philosophy Compass 6(11): 842-853. DOI: 10.1111/j.1747-9991.2011.00433.x

Watzl, Sebastian (2018). Consciousness and no self? Ratio 31(4): 363-375.

Watzl, Sebastian (2019). Can representationism explain how attention affects appearances? In Adam Pautz \& Daniel Stoljar (ed.), Blockheads! Essays on Ned Block's Philosophy of Mind and Consciousness, 581-608. Cambridge, MA: MIT Press.

Westh, Peter (2013). Anthropomorphism in god concepts: the role of narrative. $=$ Geertz 2013: 396-413.

Williams, Michael Allen (1985). The Immovable Race. A Gnostic Designation and the Theme of Stability in Late Antiquity. Leiden: E.J. Brill. 
Witzel, E. J. Michael (2012). The Origins of the World's Mythologies. Oxford University Press.

Zokaei, Nahid, Alexander G Board, Sanjay G. Manohar, and Anna C. Nobre (2019). Modulation of the pupillary response by the content of visual working memory. Proceedings of the National Academy of Sciences of the United States of America (PNAS) https://doi.org/10.1073/pnas.1909959116

\section{Abbreviation}

Handbook = Magee 2016 